\title{
Benign Ovarian Clear Cell Tumor
}

National Cancer Institute

\section{Source}

National Cancer Institute. Benign Ovarian Clear Cell Tumor. NCI Thesaurus. Code C40084.

A non-metastasizing neoplasm that arises from the ovary. It is characterized by a predominance of clear and hobnail benign epithelial cells. 